\title{
Effects of Escins Ia, Ib, IIa, and IIb from Horse Chestnut, the Seeds of Aesculus hippocastanum L., on Acute Inflammation in Animals
}

\author{
Hisashi Matsuda,${ }^{a}$ Yuhao Li,${ }^{a}$ Toshiyuki Murakami, ${ }^{a}$ Kiyofumi NinomiYa, ${ }^{a}$ \\ Johji Yamahara, ${ }^{b}$ and Masayuki YoshiKaWA ${ }^{*, a}$ \\ Kyoto Pharmaceutical University, ${ }^{5}$ Nakauchi-cho, Misasagi, Yamashina-ku, Kyoto 607, Japan and Research Institute \\ for Production Development, ${ }^{b} 15$ Morimoto-cho, Shimogamo, Sakyo-ku, Kyoto 606, Japan. \\ Received May 28, 1997; accepted July 9, 1997
}

\begin{abstract}
We investigated the effects of escins Ia, Ib, IIa, and IIb isolated from horse chestnut, the seeds of Aesculus hippocastanum L., and desacylescins I and II obtained by alkaline hydrolysis of escins on acute inflammation in animals (p.o.). Escins Ia, Ib, IIa, and IIb $(50-200 \mathrm{mg} / \mathrm{kg})$ inhibited the increase of vascular permeability induced by both acetic acid in mice and histamine in rats. Escins Ib, IIa, and IIb $(50-200 \mathrm{mg} / \mathrm{kg})$ also inhibited that induced by serotonin in rats, but escin Ia didn't. Escins Ia, Ib, IIa, and IIb $(200 \mathrm{mg} / \mathrm{kg})$ inhibited the hind paw edema induced by carrageenin at the first phase in rats. Escin Ia $(200 \mathrm{mg} / \mathrm{kg})$ and escins Ib, IIa, and IIb $(50-200 \mathrm{mg} / \mathrm{kg})$ inhibited the scratching behavior induced by compound $48 / 80$ in mice, but escin Ia was weakest. Desacylescins I and II $(200 \mathrm{mg} / \mathrm{kg})$ showed no effect. With regard to the relationship between their chemical structures and activities, the acyl groups in escins were essential. Escins Ib, IIa, and IIb with either the 21-angeloyl group or the 2 '- $O$-xylopyranosyl moiety showed more potent activities than escin Ia which had both the 21-tigloyl group and the 2 '-O-glucopyranosyl moiety.
\end{abstract}

Key words antiinflammation; escin Ia; escin Ib; escin IIa; escin IIb; Aesculus hippocastanum L.

The saponin mixture escin obtained from the seeds of the horse chestnut tree, Aesculus hippocastanum L. is widely used in the therapy of peripheral vascular disorders and in cosmetics for prevention and treatment of cellulitism. Escin has been reported to show antiinflammatory activity, ${ }^{1}$ but no experimental study of such activity has been performed using each pure saponin, because the isolation and structure determination of the saponin constituents was incomplete.

We recently isolated five pure saponins, escins $\mathrm{Ia}, \mathrm{Ib}$, IIa, IIb, and IIIa, from horse chestnut and determined their chemical structures as shown in Chart 1 . We also reported the inhibitory activities of escins $\mathrm{Ia}, \mathrm{Ib}$, IIa, and IIb on the increase of glucose or ethanol concentration in blood by oral administration of glucose or ethanol. ${ }^{2)}$ In this study, we examined the antiinflammatory activity of the principal saponins, escins Ia, Ib, IIa, and IIb, on acute inflammatory models, and showed some of the structure requirements for the activity.

\section{MATERIALS AND METHODS}

Animals Male Wistar rats and male ddY mice were purchased from Kiwa Laboratory Animal Co., Ltd. The animals were maintained in a $12 \mathrm{~h}$ light-dark cycle at a constant temperature of $23 \pm 2^{\circ} \mathrm{C}$ and were fed a standard laboratory chow (MF, Oriental Yeast Co., Ltd.). They were fasted for $15-18 \mathrm{~h}$ prior to experiments, but were supplied with water ad libitum. Test samples were suspended in $2 \%$ acacia solution and were given orally at $10 \mathrm{ml} / \mathrm{kg}$ in each experiment. The experiments were performed in conscious animals unless otherwise noted.

Acetic Acid-Induced Increase of Vascular Permeability in Mice Mice weighing 27-30 g were used. Four percent $(\mathrm{w} / \mathrm{v})$ pontamine sky blue solution in saline was injected intravenously $(10 \mathrm{ml} / \mathrm{kg})$ into the tail vein $55 \mathrm{~min}$ after the administration of a test compound. Five minutes later $1 \%$ (w/v) acetic acid solution in saline was injected intraperitoneally $(10 \mathrm{ml} / \mathrm{kg})$, and $20 \mathrm{~min}$ later the mice were sacrificed by cervical dislocation and the abdomen was immediately opened. After washing of the peritoneal cavity with $8 \mathrm{ml}$ of saline, the washed solution was filtered through glass wool, and $0.1 \mathrm{ml}$ of $1 \mathrm{~N} \mathrm{NaOH}$ was added. The solution was filled up to $10 \mathrm{ml}$ with saline, and the absorbance was measured at $590 \mathrm{~nm}$ using a spectrophotometer (model UV-1200, Shimadzu Co.). Vascular permeability was assessed by the amount of the dye which had leaked into the peritoneal cavity. Aspirin was used as a reference drug.

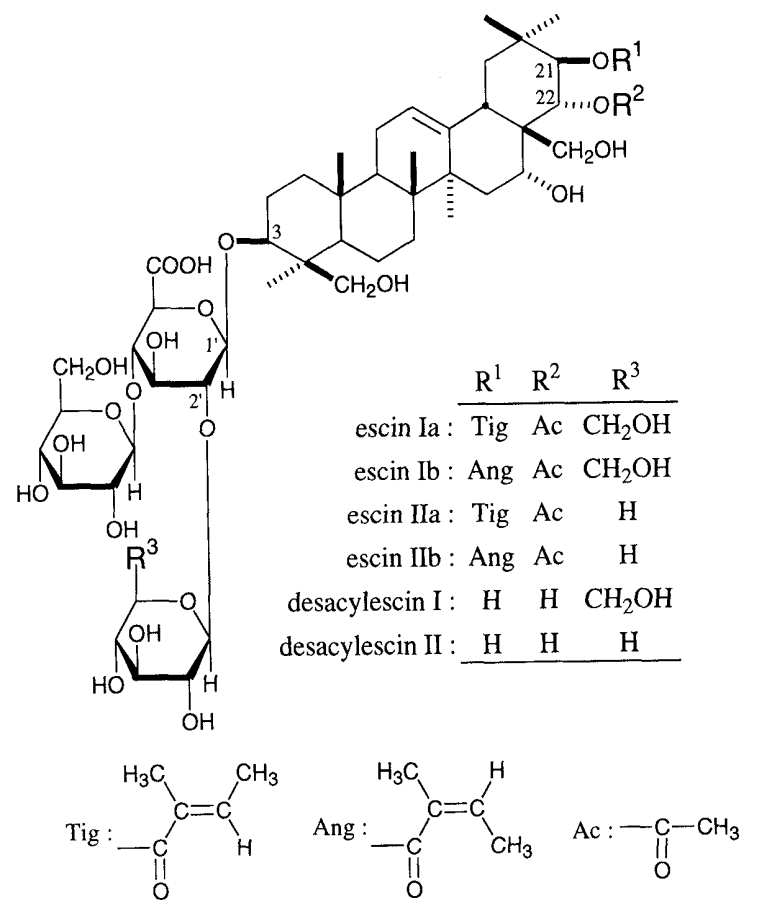

Chart 1

(c) 1997 Pharmaceutical Society of Japan 
Carrageenin-Induced Hind Paw Edema in Rats Rats weighing $140-160 \mathrm{~g}$ were used. Carrageenin was suspended in saline to make $1 \%(\mathrm{w} / \mathrm{v})$ suspension. The $0.1 \mathrm{ml}$ suspension was injected subcutaneously into the left hind paw $1 \mathrm{~h}$ after the administration of a test sample or vehicle alone. The initial volume of the hind paw was measured by a plethysmometer (model KN-357, Natsume Seisakusyo Co., Ltd.) before the administration of a test sample. Volume was also measured at intervals of $1 \mathrm{~h}$ for up to $6 \mathrm{~h}$ after the injection. The results were expressed as swelling (\%), which means the percent increase in hind paw volume as compared with the initial volume. Indomethacin was used as a reference drug.

Compound 48/80-Induced Scratching in Mice Mice weighing $26-29 \mathrm{~g}$ were used. Scratching behavior was induced by subcutaneous injection of compound $48 / 80$ at $100 \mu \mathrm{g} / 50 \mu \mathrm{l}$ saline/site into the back of mice. Scratching on the injected site by the hind paws was counted, and that of other sites such as ears was disregarded. The mice generally showed several scratches for about $1 \mathrm{~s}$ and a series of these behaviors was counted as one incident of scratching. Each test sample was given orally $1 \mathrm{~h}$ before the compound 48/80 injection. Cyproheptadine hydrochloride was used as a reference drug.

Histamine- or Serotonin-Induced Increase of Vascular Permeability in Rats Rats weighing $140-150 \mathrm{~g}$ were used. Two percent $(\mathrm{w} / \mathrm{v})$ Evans blue solution in saline was injected intravenously $(10 \mathrm{ml} / \mathrm{kg})$ into the tail vein $55 \mathrm{~min}$ after the oral administration of a test compound. Five minutes later, under light anesthesia, histamine dihydrochloride $(100 \mu \mathrm{g} / 50 \mu \mathrm{l}$ saline/site) and serotonin-creatinine sulfate monohydrate $(2.5 \mu \mathrm{g} / 50 \mu \mathrm{l}$ saline/site) were injected intracutaneously into the upper and lower back of a rat, respectively. Thirty minutes later, the animals were sacrificed by cervical dislocation, the blue colored skin in the back was cut off and soaked in $10 \mathrm{ml}$ of acetone/water $(7: 3)$ solution for $24 \mathrm{~h}$. The absorbance of the filtered solution was measured at $620 \mathrm{~nm}$. The capillary permeability was assessed by the amount of Evans blue which had leaked into the skin. Cyproheptadine hydrochloride was used as a reference drug.

Materials Escins Ia, Ib, IIa, and IIb were isolated from horse chestnut, and desacylescins I and II were obtained by alkaline hydrolysis of escins Ia and Ib, as described. ${ }^{2)}$
Reagents : Carrageenin (Picnin-A, Zushikagaku Lab., Inc.); other reagents were purchased from Wako Pure Chemical Industries.

Statistics Each value was expressed as the mean \pm S.E. Statistical significance was assessed by one-way analysis of variance following Dunnett's test for parametric data, and Kruskal-Wallis statistic on ranks following Steel's test for non-parametric data.

\section{RESULTS}

Effect on Acetic Acid-Induced Increase of Vascular Permeability in Mice By intraperitoneal injection of acetic acid, the dye was leaked into the peritoneal cavity. Aspirin $(200 \mathrm{mg} / \mathrm{kg}$, p.o. $)$ significantly inhibited the leakage of dye at about $50 \%$ inhibition. Escins Ia, Ib, IIa, and $\mathrm{IIb}(50-200 \mathrm{mg} / \mathrm{kg}$, p.o.) dose-dependently inhibited

Table 1. Effects of Escins and Desacylescins on Increase of Vascular Permeability Induced by Acetic Acid in Mice

\begin{tabular}{|c|c|c|c|c|}
\hline Treatment & $\begin{array}{c}\text { Dose } \\
(\mathrm{mg} / \mathrm{kg}, p . o .)\end{array}$ & $n$ & $\begin{array}{l}\text { Amount of } \\
\text { leaked dye } \\
(\mu \mathrm{g} / \text { animal })\end{array}$ & $\begin{array}{c}\text { Inhibition } \\
(\%)\end{array}$ \\
\hline Control & - & 12 & $422 \pm 17$ & - \\
\hline \multirow[t]{3}{*}{ Escin Ia } & 50 & 9 & $371 \pm 23$ & 12.1 \\
\hline & 100 & 10 & $293 \pm 27 * *$ & 30.6 \\
\hline & 200 & 8 & $238 \pm 27 * *$ & 43.6 \\
\hline \multirow[t]{3}{*}{ Escin $\mathrm{Ib}$} & 50 & 9 & $317 \pm 23^{*}$ & 24.8 \\
\hline & 100 & 12 & $238 \pm 20^{* *}$ & 43.6 \\
\hline & 200 & 12 & $198 \pm 31 * *$ & 53.1 \\
\hline Aspirin & 200 & 12 & $220 \pm 19^{* *}$ & 47.9 \\
\hline Control & - & 12 & $405 \pm 27$ & - \\
\hline \multirow[t]{3}{*}{ Escin IIa } & 50 & 9 & $317 \pm 29 *$ & 21.7 \\
\hline & 100 & 9 & $224 \pm 24 * *$ & 44.7 \\
\hline & 200 & 8 & $199 \pm 19 * *$ & 50.9 \\
\hline \multirow[t]{3}{*}{ Escin IIb } & 50 & 9 & $290 \pm 30 * *$ & 28.4 \\
\hline & 100 & 9 & $227 \pm 11^{* *}$ & 44.0 \\
\hline & 200 & 9 & $176 \pm 18 * *$ & 56.5 \\
\hline Aspirin & 200 & 12 & $201 \pm 17^{* *}$ & 50.4 \\
\hline Control & - & 9 & $426 \pm 16$ & - \\
\hline Desacylescin I & 200 & 9 & $414 \pm 29$ & 2.8 \\
\hline Desacylescin II & 200 & 10 & $448 \pm 50$ & -5.2 \\
\hline Aspirin & 200 & 9 & $185 \pm 17 * *$ & 56.6 \\
\hline
\end{tabular}

Significantly different from the control group, $* p<0.05, * * p<0.01$.
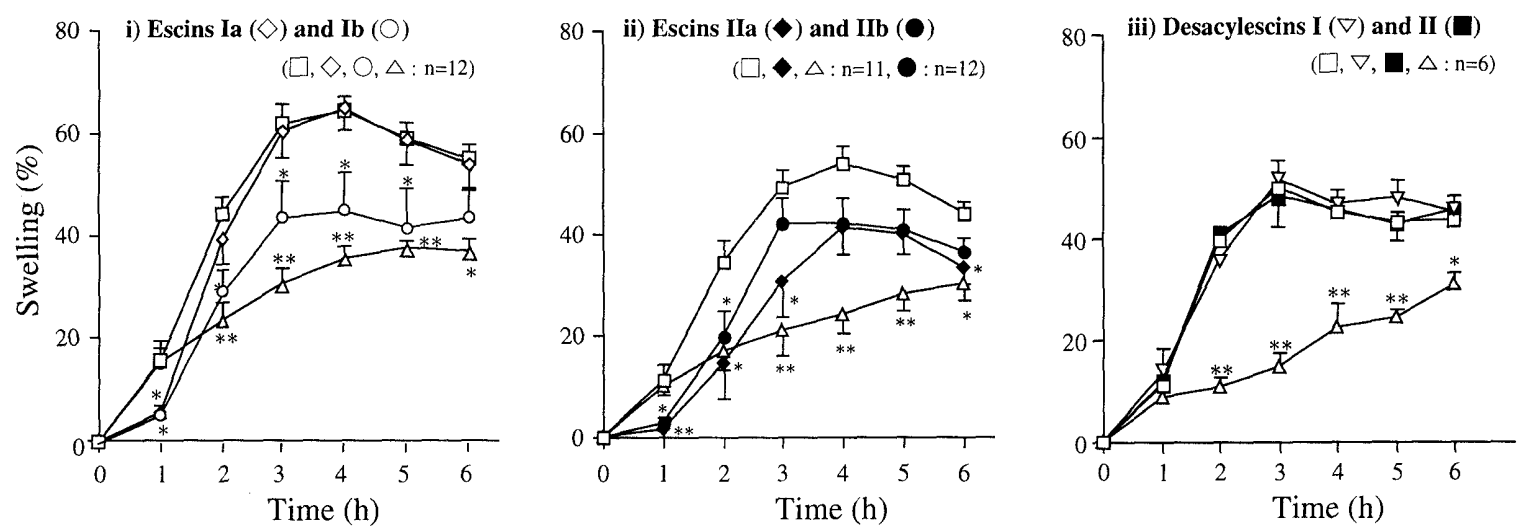

Fig. 1. Effects of Escins and Desacylescins on Hind Paw Edema Induced by Carrageenin in Rats


$(200 \mathrm{mg} / \mathrm{kg}) ; \triangle$, indomethacin $(20 \mathrm{mg} / \mathrm{kg})$. Each point represents the mean with S.E. Significantly different from the control group, $* p<0.05, * * p<0.01$. 
Table 2. Effects of Escins and Desacylescins on Scratching Behavior Induced by Compound 48/80 in Mice

\begin{tabular}{|c|c|c|c|c|}
\hline Treatment & $\begin{array}{c}\text { Dose } \\
(\mathrm{mg} / \mathrm{kg}, \text { p.o. })\end{array}$ & $n$ & $\begin{array}{l}\text { Number of } \\
\text { scratches } \\
\text { in } 30 \mathrm{~min}\end{array}$ & $\begin{array}{c}\text { Inhibition } \\
(\%)\end{array}$ \\
\hline Control & - & 10 & $138.3 \pm 14.1$ & \\
\hline \multirow{4}{*}{ Escin Ia } & 25 & 6 & $115.0 \pm 17.2$ & 16.8 \\
\hline & 50 & 6 & $93.5 \pm 13.8$ & 32.4 \\
\hline & 100 & 6 & $94.8 \pm 11.9$ & 31.5 \\
\hline & 200 & 6 & $79.7 \pm 5.6^{*}$ & 42.4 \\
\hline \multirow[t]{4}{*}{ Escin $\mathrm{Ib}$} & 25 & 6 & $103.8 \pm 22.0$ & 24.9 \\
\hline & 50 & 6 & $73.0 \pm 8.8^{*}$ & 47.2 \\
\hline & 100 & 6 & $48.3 \pm 7.9^{* *}$ & 65.1 \\
\hline & 200 & 6 & $49.7 \pm 7.9^{* *}$ & 64.1 \\
\hline Cyproheptadine & 5 & 6 & $17.8 \pm 4.4^{* *}$ & 87.1 \\
\hline Control & - & 10 & $140.2 \pm 14.2$ & \\
\hline \multirow[t]{4}{*}{ Escin IIa } & 25 & 6 & $149.2 \pm 12.3$ & -6.4 \\
\hline & 50 & 6 & $75.2 \pm 8.3^{* *}$ & 46.4 \\
\hline & 100 & 6 & $56.8 \pm 1.7^{* *}$ & 59.5 \\
\hline & 200 & 6 & $27.3 \pm 7.3^{* *}$ & 80.5 \\
\hline \multirow[t]{4}{*}{ Escin IIb } & 25 & 6 & $149.3 \pm 11.7$ & -6.5 \\
\hline & 50 & 6 & $85.3 \pm 7.1^{*}$ & 39.2 \\
\hline & 100 & 6 & $73.0 \pm 8.1^{* *}$ & 47.9 \\
\hline & 200 & 6 & $34.2 \pm 8.1^{* *}$ & 75.6 \\
\hline Cyproheptadine & 5 & 6 & $19.3 \pm 3.8^{* *}$ & 86.2 \\
\hline Control & - & 10 & $130.5 \pm 9.1$ & \\
\hline Desacylescin I & 200 & 6 & $103.5 \pm 12.9$ & 20.7 \\
\hline Desacylescin II & 200 & 6 & $118.7 \pm 12.5$ & 9.0 \\
\hline Cyproheptadine & 5 & 6 & $26.3 \pm 4.8^{* *}$ & 79.8 \\
\hline
\end{tabular}

Significantly different from the control group, $* p<0.05, * * p<0.01$.

the leakage as shown in Table 1, while desacylescins I and II $(200 \mathrm{mg} / \mathrm{kg}$, p.o. $)$ showed no effect on it.

Effect on Carrageenin-Induced Hind Paw Edema in Rats By subcutaneous injection of carrageenin into rat hind paw, the swelling was advanced and maintained for 1 to $6 \mathrm{~h}$ after the injection. Maximum swelling was observed at 3 to $5 \mathrm{~h}$. As shown in Fig. 1, indomethacin $(20 \mathrm{mg} / \mathrm{kg}$, p.o.) showed significant inhibition at 2 to $6 \mathrm{~h}$, but not at $1 \mathrm{~h}$. Escin Ia $(200 \mathrm{mg} / \mathrm{kg}$, p.o. $)$ significantly inhibited the swelling at $1 \mathrm{~h}$, but showed no effect at 3 to $5 \mathrm{~h}$. Escin Ib $(200 \mathrm{mg} / \mathrm{kg}$, p.o. $)$ significantly inhibited the swelling at 1 to $5 \mathrm{~h}$. Escins IIa and $\mathrm{IIb}(200 \mathrm{mg} / \mathrm{kg}$, p.o.) inhibited the swelling at 1 to $2 \mathrm{~h}$, and tended to suppress the swelling at 3 to $5 \mathrm{~h}$. Desacylescins I and II ( $200 \mathrm{mg} / \mathrm{kg}$, p.o. $)$ showed no effect on it.

Effect on Compound 48/80-Induced Scratching in Mice Subcutaneous injection of compound 48/80 into the back of mice induced scratching behavior. The number of scratches was about 130 within $30 \mathrm{~min}$ after the injection. As is apparent from Table 2, escins Ia $(200 \mathrm{mg} / \mathrm{kg}$, p.o.) and escins Ib, IIa, and IIb (50-200 $\mathrm{mg} / \mathrm{kg}$, p.o.) significantly inhibited the behavior, but desacylescins I and II $(200 \mathrm{mg} / \mathrm{kg}$, p.o. $)$ showed no significant inhibition. In addition, escins IIa and IIb showed much more potent inhibition than escin $\mathrm{Ia}$ and $\mathrm{Ib}$ at $200 \mathrm{mg} / \mathrm{kg}$, and escin $\mathrm{Ib}$ showed more potent inhibition than escin Ia. Cyproheptadine $(5 \mathrm{mg} / \mathrm{kg}$, p.o. $)$ strongly inhibited the behavior.

Effect on Histamine- or Serotonin-Induced Increase of Vascular Permeability in Rats By intracutaneous injection of histamine or serotonin, the dye was leaked into
Table 3. Effects of Escins and Desacylescins on Increase of Vascular Permeability Induced by Histamine or Serotonin in Rats

\begin{tabular}{|c|c|c|c|c|}
\hline Treatment & $\begin{array}{c}\text { Dose } \\
(\mathrm{mg} / \mathrm{kg}, \text { p.o. })\end{array}$ & $n$ & $\begin{array}{l}\text { Histamine } \\
\text { Amount of } \\
\text { dye }(\mu \mathrm{g} / \text { site })\end{array}$ & $\begin{array}{c}\text { Serotonin } \\
\text { Amount of } \\
\text { dye }(\mu \mathrm{g} / \mathrm{site})\end{array}$ \\
\hline $\begin{array}{l}\text { Sham operation } \\
\text { (saline) }\end{array}$ & - & 6 & $7.9 \pm 0.8^{* *}$ & $7.9 \pm 0.8^{* *}$ \\
\hline Control & - & 8 & $52.6 \pm 6.5$ & $55.0 \pm 2.3$ \\
\hline \multirow[t]{4}{*}{ Escin Ia } & 25 & 6 & $46.1 \pm 4.1$ & $41.5 \pm 8.0$ \\
\hline & 50 & 6 & $28.4 \pm 4.7^{* *}$ & $43.1 \pm 6.0$ \\
\hline & 100 & 6 & $28.5 \pm 2.7^{* *}$ & $40.9 \pm 4.7$ \\
\hline & 200 & 6 & $19.4 \pm 2.1^{* *}$ & $43.3 \pm 5.1$ \\
\hline \multirow[t]{4}{*}{ Escin Ib } & 25 & 6 & $53.3 \pm 5.1$ & $44.0 \pm 7.2$ \\
\hline & 50 & 6 & $30.8 \pm 4.2^{* *}$ & $36.4 \pm 6.0^{* *}$ \\
\hline & 100 & 6 & $28.1 \pm 3.4^{* *}$ & $30.5 \pm 2.6^{* *}$ \\
\hline & 200 & 6 & $22.0 \pm 2.3^{* *}$ & $28.0 \pm 3.1^{* *}$ \\
\hline Cyproheptadine & 5 & 6 & $22.6 \pm 3.1 * *$ & $14.4 \pm 2.6^{* *}$ \\
\hline $\begin{array}{l}\text { Sham operation } \\
\text { (saline) }\end{array}$ & - & 6 & $10.3 \pm 0.7^{* *}$ & $10.3 \pm 0.7^{* *}$ \\
\hline Control & - & 10 & $58.7 \pm 2.9$ & $63.0 \pm 3.2$ \\
\hline \multirow[t]{4}{*}{ Escin IIa } & 25 & 6 & $54.3 \pm 3.5$ & $54.7 \pm 3.7$ \\
\hline & 50 & 6 & $46.6 \pm 2.5^{*}$ & $38.2 \pm 4.1^{* *}$ \\
\hline & 100 & 6 & $40.3 \pm 3.4^{* *}$ & $29.1 \pm 4.5^{* *}$ \\
\hline & 200 & 6 & $23.2 \pm 3.4^{* *}$ & $31.9 \pm 2.0^{* *}$ \\
\hline \multirow[t]{4}{*}{ Escin IIb } & 25 & 6 & $51.0 \pm 3.5$ & $55.4 \pm 2.8$ \\
\hline & 50 & 6 & $45.4 \pm 4.8^{*}$ & $44.0 \pm 3.3^{* *}$ \\
\hline & 100 & 6 & $37.3 \pm 3.7^{* *}$ & $40.6 \pm 4.7 * *$ \\
\hline & 200 & 6 & $29.3 \pm 2.7^{* *}$ & $29.7 \pm 1.9^{* *}$ \\
\hline Cyproheptadine & 5 & 6 & $23.1 \pm 2.2^{* *}$ & $21.1 \pm 1.7^{* *}$ \\
\hline Control & - & 10 & $61.4 \pm 3.1$ & $72.6 \pm 4.6$ \\
\hline Desacylescin I & 200 & 6 & $57.5 \pm 7.2$ & $62.7 \pm 9.5$ \\
\hline Desacylescin II & 200 & 6 & $72.8 \pm 5.6$ & $68.7 \pm 4.3$ \\
\hline Cyproheptadine & 5 & 6 & $33.2 \pm 3.4^{* *}$ & $28.3 \pm 2.4^{* *}$ \\
\hline
\end{tabular}

Significantly different from the control group, $* p<0.05, * * p<0.01$.

the skin. Escins Ia, Ib, IIa, and IIb $(50-200 \mathrm{mg} / \mathrm{kg})$ dose-dependently inhibited the increase of extravasated dye induced by histamine as shown in Table 3. Escin Ib, IIa, and IIb (50-200 mg/kg, p.o.) also dose-dependently inhibited the increase of extravasated dye induced by serotonin, but escin Ia $(25-200 \mathrm{mg} / \mathrm{kg}$, p.o.) lacked significant inhibition of it. Desacylescins I and II $(200 \mathrm{mg} / \mathrm{kg}$, p.o.) also showed no significant inhibition against either histamine or serotonin-induced vascular permeability.

\section{DISCUSSION}

The development of edema induced by carrageenin and the increase of vascular permeability induced by acetic acid are known to correspond to the early exudative stage of inflammation, one of the important processes of inflammatory pathology. ${ }^{3)}$ Histamine and serotonin are presumed to play an important role in the first stage of carrageenin-induced edema and acetic acid-induced increase of vascular permeability.

We investigated the antiinflammatory activities of pure escins Ia, Ib, IIa, and IIb, which were isolated from horse chestnut and were the principal ingredients of escin in acute inflammatory models. Escins dose-dependently exhibited inhibitory effects on the increase of vascular permeability by acetic acid in mice, and on the earlier 
phase of swelling by carrageenin in rats. Escin Ib (200 $\mathrm{mg} / \mathrm{kg}$, p.o.) showed significant inhibition on the second phase of swelling by carrageenin, and escins IIa and IIb also showed a tendency to inhibit it. All escins inhibited histamine-induced increase of vascular permeability, and escins Ib, IIa, and IIb also inhibited serotonin-induced that. Compound $48 / 80$-induced scratching behavior is thought to be due to an itch caused by the released chemical mediators ${ }^{4)}$ so we examined the inhibitory activity of escins on this and found they significantly inhibited the behavior. These results indicate that escins, given orally, affect the early exudative stage of inflammation and itch owing to these chemical mediators and suggest that these inhibitory effects are mainly dependent on their antihistaminic and anti-serotoninergic activities, though the effects of escins against kinin formation and arachidonic acid cascade remain unknown.

Comparison of escins $\mathrm{Ia}$ and $\mathrm{Ib}$ with the $2^{\prime}-\mathrm{O}$ glucopyranosyl moiety showed escin $\mathrm{Ib}$ with the 21angeloyl group to have more potent activities than escin Ia with the 21-tigloyl group in carrageenin-induced edema at the second phase, compound 48/80-induced scratching behavior and serotonin-induced vascular permeability. Escin IIa with the 2'-O-xylopyranoside and 21-tigloyl groups also showed more potent activities than escin Ia with 2'-O-glucopyranosyl moiety and the 21-tigloyl group. But escins Ib, IIa, and IIb having either the 2'-Oxylopyranosyl moiety or the 21-angeloyl group exhibited similar effects in these experiments; desacylescins lacked the activity. These results led us to presume the following structure-requirements of escins for the activity : 1) the 21- and 22-acyl groups were essential to the activity; 2) the 21-angeloyl group more than the 21-tigloyl group intensified the activity; 3 ) the $2^{\prime}-O$-xylopyranosyl moiety more than the 2'-O-glucopyranosyl moiety also intensified the activity.

The saponin mixture escin has been clinically used and pharmacologically evaluated without further purification, so that the detailed antiinflammatory activity of each saponin constituents has been left uncharacterized. In this study, it was apparent that escins have antiinflammatory activities in the acute stage, but there are remarkable differences among the activity of each escin, especially anti-serotoninergic activity. Furthermore, the differences of chemical structure in acyl groups and oligosaccharide moiety are apparently important for exhibit of the antiinflammatory activity. Escin Ia has been frequently referred to as representative of escin. Since escin Ia was found to show less activity, escins Ib, IIa, or IIb should be cited in the literature as the antiinflammatory principle of escin.

\section{REFERENCES}

1) a) Vogel G., Marek M. L., Stoeckert I., Arzneim. Forsch., 13, 59-64 (1963); b) Vogel G., Marek M. L., Oertner R., ibid., 20, 699-703 (1970); c) Ogura M., Suzuki K., Tamada T., Fujimoto Y., Pharmacometrics, 9, 883-894 (1975); d) Rothkopf M., Vogel G., Arzneim. Forsch., 26, 225-235 (1976).

2) a) Yoshikawa M., Harada E., Murakami T., Matsuda H., Wariishi N., Yamahara J., Murakami N., Kitagawa I., Chem. Pharm. Bull., 42, 1357-1359 (1994); b) Yoshikawa M., Murakami T., Matsuda H., Yamahara J., Murakami N., Kitagawa I., ibid., 44, $1454-1464$ (1996).

3) a) Whittle B. A., Br. J. Pharmacol., 22, 246-253 (1964); b) Winter C. A., Risley E. A., Nuss G. W., Proc. Soc. Exp. Biol. Med., 111, 544-547 (1962).

4) a) Kuraishi Y., Nagasawa T., Hayashi K., Satoh M., Eur. J. Pharmacol., 275, 229 - 233 (1995); b) Kubo M., Matsuda H., Dai Y., Ido Y., Yoshikawa M., Yakugaku Zasshi, 117, 193-201 (1997). 